\title{
Component population study of Acanthocephalus tumescens (Acanthocephala) in fishes from Lake Moreno, Argentina
}

\author{
Carlos A. Rauque, Gustavo P. Viozzi and Liliana G. Semenas
}

Laboratorio de Parasitología, Centro Regional Universitario Bariloche, Universidad Nacional del Comahue, Quintral 1250, (8400) San Carlos de Bariloche, Río Negro, Argentina

Key words: Acanthocephalus tumescens, Patagonian freshwater fishes, host status, component population, suprapopulation

\begin{abstract}
Seasonal samples of all fish species from Lake Moreno were taken in order to determine the presence of paratenia, to evaluate the status of the hosts and to characterise the transmission of Acanthocephalus tumescens (von Linstow, 1896) at the component population level. Prevalence, mean abundance, mean intensity, numbers of gravid females, relative abundance of the different fish species, relative output of eggs and relative flow rates for each host species were computed. Acanthocephalus tumescens showed low host specificity, successfully parasitizing six out of eight fish species present in the lake. No paratenic infection was registered. If prevalence, mean abundance, and number of gravid females are considered, host species can be placed in a continuum from the most to least suitable as follows: Galaxias platei Steindachner, Diplomystes viedmensis (Mac Donagh), Oncorhynchus mykiss (Walbaum), Salvelinus fontinalis (Mitchill), Percichthys trucha (Cuvier et Valenciennes) and Galaxias maculatus (Jenyns). However, when parasite flow rates and egg output were calculated, including relative abundance of each fish species, the continuum was rearranged as follows: P. trucha, O. mykiss, G. platei / G. maculatus, S. fontinalis and D. viedmensis. The first four species would be the main contributors to the population of $A$. tumescens in this lake, $P$. trucha being the major one. Different regulatory and non-regulatory mechanisms are suggested.
\end{abstract}

Although the acanthocephalans with aquatic cycles can infect a wide range of fish hosts, in only a few of them can they establish themselves, reach the proper size, and attain sexual maturity (Crompton 1983, Kennedy 1993). For this reason, the host status should not be assigned only by the presence of the parasite (Hine and Kennedy 1974). Causes such as the food requirements of the parasite and diet and immune response of the host could determine this transmission pattern (Kennedy 1993). Different systems of classification have been worked out in order to establish the host status. Amin (1987) refers to principal, accessory and occasional host, and Holmes $(1976,1979)$ classifies them as required, suitable and unsuitable. These classification systems have been established using variables such as mean intensity and prevalence of infection, size and growth of parasites and maturity and proportion of gravid females. The proportion of gravid females is very important for the assessment of relative parasite flow rates through the different species of definitive hosts (Esch and Fernández 1993). The relative abundance of each fish host species, seldom considered, also contributes to a sharper evaluation of the relative flow of parasites at the component population level (Holmes et al. 1977). Particularly in this type of study, post-cyclic transmission and the presence of paratenic hosts should also be considered.

In Argentina research about host status for acanthocephalans has been carried out for Pomphorhynchus patagonicus Ortubay, Úbeda, Semenas et Kennedy,
1991 and P. sphaericus Gil de Pertierra, Spatz et Doma, 1996 (Úbeda et al. 1994, Gil de Pertierra et al. 1996). In Patagonia, Úbeda et al. (1994) found Odontesthes hatcheri (Eigenmann) as principal host, Galaxias platei Steindachner as secondary and Oncorhynchus mykiss (Walbaum) would act as a sink for $P$. patagonicus. Trejo (1994) also suggested the importance of the assemblage of fishes, feeding habits and environmental characteristics which vary among sites in order to assess the sustainability of $P$. patagonicus.

Acanthocephalus tumescens (von Linstow, 1896), the other acanthocephalan species in Patagonian freshwater systems has been found parasitizing the intestine of native fishes such as Galaxias maculatus Jenyns, $G$. platei, Diplomystes viedmensis (Mac Donagh), Odontesthes hatcheri, Percichthys trucha (Cuvier et Valenciennes) and $P$. colhuapiensis Mac Donagh and introduced species such as Oncorhynchus mykiss, Salmo trutta (Linnaeus), S. salar Linnaeus, Salvelinus fontinalis (Mitchill) and Salvelinus namaycush (Walbaum) (Torres et al. 1990, 1992, Ortubay et al. 1994, Semenas and Trejo 1997). The intermediate host is the amphipod Hyalella patagonica Ortmann, 1911 (Trejo et al. 2000).

Considering the wide host range for A. tumescens, and the differences in size and feeding behaviour of its hosts, phenomena such as post-cyclic transmission, paratenia and different host status could be suspected. Post-cyclic transmission has been proven for $A$. tumescens (Rauque et al. 2002), so the aims of this study were to determine the presence of paratenia, to 
evaluate the status of the hosts for $A$. tumescens and to characterise the transmission of this acanthocephalan at the component population level in Lake Moreno.

\section{MATERIALS AND METHODS}

\section{Study site and fish characteristics}

Lake Moreno $\left(41^{\circ} 04^{\prime} \mathrm{S}, 71^{\circ} 33^{\prime} \mathrm{W}\right)$ flows towards the Atlantic, is oligotrophic and is of glacial origin. This lake has a surface area of $10.3 \mathrm{~km}^{2}$, is located at $764 \mathrm{~m}$ a.s.l. and has a maximum depth of $112 \mathrm{~m}$. Native fish species such as $G$. maculatus, G. platei, D. viedmensis, $O$. hatcheri and $P$. trucha and introduced species such as $O$. mykiss, S. trutta and $S$. fontinalis are found in this lake.

Galaxias maculatus is the smallest fish in the lake, attaining $10 \mathrm{~cm}$ in length. It feeds on zooplanktonic and benthic organisms, swims in schools near the coast and is the major prey category for the other fishes (Macchi et al. 1999). Galaxias platei attains $35 \mathrm{~cm}$ in length and has a benthic habit; includes a wide range of prey in its diet, although $H$. patagonica is the most frequent (Úbeda et al. 1994). Percichthys trucha is the largest native fish, attaining $40 \mathrm{~cm}$ in length, and is mainly a benthic feeder, although it includes $G$. maculatus in its diet. It has a benthic habit and only its young specimens are preyed on by salmonids. Odontesthes hatcheri attains $20 \mathrm{~cm}$ in length and is mainly pelagic, omnivorous, feeding on zooplankton and zoobenthos and the largest specimens can be piscivorous (Macchi et al. 1999). Only young specimens are preyed on by salmonids. Diplomystes viedmensis attains $30 \mathrm{~cm}$ in length, feeding on insects and fishes. It has a benthic habit, being eaten exclusively by salmonids (Macchi et al. 1999). The salmonids are the largest fishes in the lake, are visual predators and potentially piscivorous when the availability of other prey is low (Macchi et al. 1999).

\section{Data collection}

Seasonal samples of all fish species in Lake Moreno were taken from November 1999 to August 2000. Specimens of $G$. maculatus were collected with net traps from the coast, transported to the laboratory and kept alive for up to 3 days until examined. The other fish species were captured using gillnets of various mesh sizes located in several places in the lake, from the coast to a depth of $50 \mathrm{~m}$. These fishes were sacrificed and immediately brought to the laboratory. The intestines of all the fishes were removed and opened longitudinally in order to recover adult acanthocephalans and the other helminth species. The other abdominal organs were also checked in order to detect paratenic acanthocephalans. All the helminth parasites in the fish' intestines were counted. Also the content of stomachs was examined for food items. The relative CPUE (capture per unit effort) of all the sampled fishes $(n=1440)$ was used to evaluate the relative abundance of each host species from Lake Moreno. Although $G$. maculatus was captured with a different sampling method, its CPUE was also used.

Prevalence, mean abundance and mean intensity were calculated according to Bush et al. (1997). The sex of the acanthocephalans was recorded and the females were assigned to one of three categories: F1 immature with ovarian balls only, F2 with maturing eggs, and F3 with fully mature shelled eggs. The host status was analysed following Holmes (1979) and Amin (1987).

In order to study the relative flow rates of $A$. tumescens through each host species in Lake Moreno, mean abundance in a given host species was multiplied by the relative abundance of that host and then adjusted to a proportion of the total flow (sum of partial flows) of all host species (Holmes et al. 1977). The relative egg output from each host species was taken as the mean abundance of $A$. tumescens in a given host species multiplied by the percentage of F3 females in that host, multiplied by the relative abundance of that host in the lake, and then adjusted to a proportion of the total output (Holmes et al. 1977).

In order to detect potential interactions, a Spearman Rank Correlation Test (Conover 1980) was used to analyse the covariation of $A$. tumescens abundance with the percentage of F3 females and with the abundance of the other parasite species. If negative co-variation between species was detected, correlation with intensity would be also tested.

\section{RESULTS}

Of the total number of fish captured, 882 specimens were analysed; numbers of each species and length fish range are shown in Table 1. Acanthocephalus tumescens infected six fish species belonging to four different families (Galaxiidae, Diplomystidae, Percichthyidae and Salmonidae). Only the specimens of Odontesthes hatcheri and Salmo trutta were not infected (Table 1).

All adult acanthocephalans recovered were normally attached in the intestine of fishes, and free larvae were found in the stomach of Percichthys trucha, Galaxias platei and Salvelinus fontinalis. No paratenic infection was found, since no acanthocephalans were recovered from the other abdominal organs.

The native fishes, Diplomystes viedmensis and $G$. platei registered the highest values for prevalence, mean intensity and mean abundance (Table 1). Among the introduced species, $S$. fontinalis had the highest values for prevalence and Oncorhynchus mykiss, the highest values for mean intensity and mean abundance (Table 1). Galaxias maculatus had the highest values for F3 females among native fishes and $S$. fontinalis and $O$. mykiss among introduced ones (Table 1).

Major items found in the stomachs of all fishes were crustaceans such as Hyalella patagonica, insects, gastropods, annelids and G. maculatus as the only species of fish. Hyalella patagonica and G. maculatus are the only registered sources of $A$. tumescens infection, so the percentages of fishes containing them in the gut content are indicated in Table 2. The six host fish species fed on $H$. patagonica but only four fed on $G$. maculatus. A high percentage of $G$. platei fed on $H$. patagonica but $S$. fontinalis, O. mykiss and P. trucha showed the major percentages for $G$. maculatus. Also $O$. hatcheri and $S$. trutta fed on G. maculatus, but only the former fed on H. patagonica, too (Table 2). 
Table 1. Number and length range of examined fish, prevalence, number of parasites, mean intensity, mean abundance, and percentage of F3 females from each fish species for Acanthocephalus tumescens in Lake Moreno.

\begin{tabular}{|l|l|c|c|c|c|c|c|}
\hline & $\begin{array}{c}\text { Host } \\
\text { (No. examined } \\
\text { fish) }\end{array}$ & $\begin{array}{c}\text { Length range } \\
\text { of fish (cm) }\end{array}$ & $\begin{array}{c}\text { Prevalence } \\
(\%)\end{array}$ & $\begin{array}{c}\text { No. } \\
\text { parasites }\end{array}$ & $\begin{array}{c}\text { Mean intensity } \\
\pm \text { SD }\end{array}$ & $\begin{array}{c}\text { Mean } \\
\text { abundance } \\
\pm \text { SD }\end{array}$ & $\begin{array}{c}\text { Percentage of } \\
\text { F3 females }\end{array}$ \\
\hline Percichthyidae & P. trucha (157) & $9.5-43$ & 34.7 & 534 & $10.3 \pm 14.9$ & $3.4 \pm 9.8$ & 6.9 \\
\hline Galaxiidae & $\begin{array}{l}\text { G. platei (36) } \\
\text { G. maculatus } \\
\text { (568) }\end{array}$ & $10.5-26.5$ & 52.8 & 289 & $15.2 \pm 17.0$ & $8 \pm 14.4$ & 11.4 \\
\hline \multirow{3}{*}{ Salmonidae } & O. mykiss (63) & $10-9$ & 1.8 & 22 & $2.2 \pm 1.8$ & $0.04 \pm 0.4$ & 25 \\
& S. fontinalis (33) & $11-39.5$ & 43.0 & 182 & $8.7 \pm 10.0$ & $2.9 \pm 7.1$ & 17.7 \\
& S. trutta (1) & 66 & 0 & 58 & $3.6 \pm 3.7$ & $1.8 \pm 3.1$ & 16.1 \\
\hline Diplomystidae & D. viedmensis (9) & $14.3-19.5$ & 55.5 & 134 & $26.8 \pm 37.0$ & $14.9 \pm 29.3$ & 6.2 \\
\hline Atherinidae & O. hatcheri (15) & $28-36$ & 0 & 0 & 0 & 0 & 0 \\
\hline
\end{tabular}

Table 2. Percentage of each fish species containing Galaxias maculatus or Hyalella patagonica in the gut content.

\begin{tabular}{|l|c|c|}
\hline \multicolumn{1}{|c|}{ Host } & $\begin{array}{c}\text { Percentage containing } \\
\text { G. maculatus }\end{array}$ & $\begin{array}{c}\text { Percentage containing } \\
\text { H. patagonica }\end{array}$ \\
\hline Percichthys trucha & 30 & 33.7 \\
Galaxias platei & 8.6 & 74.3 \\
Galaxias maculatus & - & 2.2 \\
Oncorhynchus mykiss & 41.3 & 22.2 \\
Salvelinus fontinalis & 51.5 & 33.3 \\
Salmo trutta & 100 & 0 \\
Diplomystes viedmensis & 0 & 44 \\
Odontesthes hatcheri & 6.7 & 6.7 \\
\hline
\end{tabular}

Table 3. Relative abundance of fish host and flow rates and output of Acanthocephalus tumescens eggs for each fish host in Lake Moreno.

\begin{tabular}{|l|c|c|c|}
\hline \multicolumn{1}{|c|}{ Host } & $\begin{array}{c}\text { Relative abundance } \\
(\%)\end{array}$ & $\begin{array}{c}\text { Flow rates } \\
(\%)\end{array}$ & $\begin{array}{c}\text { Egg output } \\
(\%)\end{array}$ \\
\hline Percichthys trucha & 12.2 & 71.7 & 51.1 \\
Galaxias platei & 0.6 & 8.3 & 9.8 \\
Galaxias maculatus & 83.8 & 5.8 & 15 \\
Oncorhynchus mykiss & 2.1 & 10.5 & 19.3 \\
Salvelinus fontinalis & 0.8 & 2.4 & 4 \\
Diplomystes viedmensis & 0.05 & 1.2 & 0.8 \\
\hline
\end{tabular}

* data by Pablo Vigliano and Patricio Macchi, pers. comm.

Table 4. Mean abundance \pm SD for each parasite species recovered from the intestine of the fish hosts of Acanthocephalus tumescens in Lake Moreno.

\begin{tabular}{|c|c|c|c|c|c|c|}
\hline & P. trucha & G. platei & G. maculatus & O. mykiss & S. fontinalis & D. viedmensis \\
\hline Austrocreadium sp. & $0.012 \pm 0.2$ & 0 & 0 & 0 & 0 & 0 \\
\hline Polylekithum percai $*$ & $1.6 \pm 5.9$ & 0 & 0 & 0 & 0 & 0 \\
\hline $\begin{array}{l}\text { Acanthostomoides } \\
\text { apophalliformis }\end{array}$ & $225.2 \pm 432.5$ & $0.1 \pm 0.3$ & 0 & $0.4 \pm 2.1$ & $3.3 \pm 13.8$ & $0.2 \pm 0.4$ \\
\hline Nippotaenia sp. & $0.012 \pm 0.1$ & $0.5 \pm 1.3$ & $0.8 \pm 3.0$ & $0.3 \pm 1.9$ & $0.3 \pm 1.6$ & 0 \\
\hline Camallanus corderoi & $28.8 \pm 45.5$ & $0.1 \pm 0.2$ & $0.3 \pm 2.1$ & $0.8 \pm 2.4$ & $5.3 \pm 11.1$ & 0 \\
\hline $\begin{array}{l}\text { Nomimoscolex } \\
\text { semenasae ** }\end{array}$ & 0 & 0 & 0 & 0 & 0 & $2.8 \pm 3.3$ \\
\hline $\begin{array}{l}\text { Hysterothylacium } \\
\text { patagonense } * * *\end{array}$ & $4.6 \pm 19.9$ & $0.4 \pm 1.1$ & 0 & $0.4 \pm 1.0$ & $4.1 \pm 12.4$ & $3.1 \pm 5.1$ \\
\hline
\end{tabular}

* P. percai Ostrowski de Núñez, Brugui et Viozzi, 2000; ** N. semenasae Gil de Pertierra, 2002; *** H. patagonense Moravec, Urawa et Coria, 1997 
Data of relative abundance of each fish species, flow rates of parasites and output of eggs are shown in Table 3. Percichthys trucha, O. mykiss and G. maculatus had the major values for egg output and P. trucha, O. mykiss and $G$. platei for parasite transmission.

When co-variation between intensity of $A$. tumescens and percentage of F3 females was analysed, $P$. trucha $(\mathrm{rS}=0.429 ; \mathrm{n}=52 ; \mathrm{P}<0.05)$, G. maculatus $(\mathrm{rS}=0.719 ; \mathrm{n}=10 ; \mathrm{P}<0.05)$ and O. mykiss $(\mathrm{rS}=$ $0.546 ; \mathrm{n}=22 ; \mathrm{P}<0.05)$ had a positive one and the other fish species showed no co-variation.

The mean abundance of the other intestinal parasite species recorded for the six fish hosts are shown in Table 4. Only the digenean Acanthostomoides apophalliformis Szidat, 1956 and the nematode Camallanus corderoi Torres, Teuber et Miranda, 1990 in P. trucha were abundant enough to be used for test correlations. The abundance of $A$. apophalliformis co-varied positively with the percentage of $\mathrm{F} 3$ females $(\mathrm{rS}=0.138$; $\mathrm{n}=157 ; \mathrm{P}<0.05)$ and with the abundance of $A$. tumescens ( $\mathrm{rS}=-0.254 ; \mathrm{n}=157 ; \mathrm{P}<0.05)$. The abundance of $C$. corderoi did not co-vary with the percentage of $\mathrm{F} 3$ females $(\mathrm{rS}=-0.02 ; \mathrm{n}=157 ; \mathrm{P}>$ 0.05 ) and negatively co-varied with the abundance of $A$. tumescens $(\mathrm{rS}=-0.15 ; \mathrm{n}=157 ; \mathrm{P}<0.05)$. However, when correlation tests between intensities of $C$. corderoi and $A$. tumescens were performed no co-variation was found $(\mathrm{rS}=-0.126 ; \mathrm{n}=44 ; \mathrm{P}>0.05)$.

\section{DISCUSSION}

Nickol (1985), reviewing acanthocephalan infections, did not find paratenic hosts for species of Acanthocephalus. In agreement with this, no paratenic infections of Acanthocephalus tumescens were found in Lake Moreno. The free larvae found in the stomach of the fishes would come from recently ingested amphipods. Post-cyclic transmission of $A$. tumescens from Galaxias maculatus to other fishes could be suspected, as the former is the major prey category for the other Patagonian freshwater fishes (Macchi et al. 1999). Until now this kind of transmission has only been proven for Oncorhynchus mykiss (Rauque et al. 2002).

Maturity of females, prevalence, mean abundance and mean intensity of infection and growth of acanthocephalans are used to evaluate the host status (Holmes 1979, Amin 1987). Characteristics of parasitic population can be precisely established when these variables have extreme values, however, the intermediate cases are difficult to classify. Holmes (1979) also suggested a continuum of hosts from which the parasites never become established to those in which the parasites develop best. Considering the low specificity of $A$. tumescens which successfully parasitizes six out of eight fish species, such a continuum seems to be more appropriate in describing the status of hosts in Lake Moreno. A potential energy wastage due to the loss of cystacanths seems to be diminished in A. tumescens because almost all the fish species were parasitized, having considerable percentages of gravid females. Therefore, in Lake Moreno all the hosts could contribute to the overall reproduction activity of the parasite.

Ortubay et al. (1994) cited Odontesthes hatcheri and Salmo trutta parasitized by $A$. tumescens in Patagonian lakes, but no infection was registered in Lake Moreno. Salmo trutta is highly piscivorous, preying on $G$. maculatus (Macchi et al. 1999), however, no infection was recorded probably due to its small sample size. One $O$. hatcheri out of 15 had Hyalella patagonica or G. maculatus in stomach, so its pelagic feeding habit (Macchi et al. 1999) would reduce exposure to infection. Additional studies are required to confirm the status of these fish species in Lake Moreno.

Following the criteria used by Amin (1987), all the hosts in Lake Moreno except G. maculatus, would be principal ones, and could be arranged in a decreasing suitability rank, considering the percentage of F3 females, prevalence and mean intensity as follows: Galaxias platei, Diplomystes viedmensis, O. mykiss, Salvelinus fontinalis, Percichthys trucha and G. maculatus. Although prevalence, mean intensity and reproductive potential of parasites are relevant indicators of the primary hosts, when a parasite species has low specificity, and the host species do not show great differences in those parameters, the analysis of the relative flow rates of the parasites through each host population is important (Holmes et al. 1977). If a decreasing continuum of parasite flow rates and egg output is considered, the suitability rank of host species could be arranged as follows: P. trucha, O. mykiss, G. platei / G. maculatus, S. fontinalis, and D. viedmensis. The position of $G$. platei and $G$. maculatus varied if transmission rates or output of eggs are considered. This continuum seems to be more appropriate in our study than the previous one because of the low specificity of A. tumescens and its ability to successfully establish itself in almost all fish species in this lake. In our hostparasite system, G. maculatus seems to be an unsuitable host due to the low values of prevalence and mean intensity, however its high percentage of F3 females and relative abundance make it one of the main contributor to sustain A. tumescens population in Lake Moreno. An abundant fish species like $P$. trucha with intermediate values of prevalence and mean intensity would be more important to the population of the parasite than highly parasitized scarce species, like D. viedmensis. As Holmes (1979) pointed out, the structure of the host community has the potential to affect the population dynamics of the parasite species. Interspecific relationships between hosts, like prey-predator one, should also be considered, specially in our case where post-cyclic transmission is suspected for all the fish hosts. If flow rates of parasites, output of eggs and post-cyclic transmission are considered the overall flow of $A$. tumescens in Lake Moreno can be summarised as in Fig. 1. 


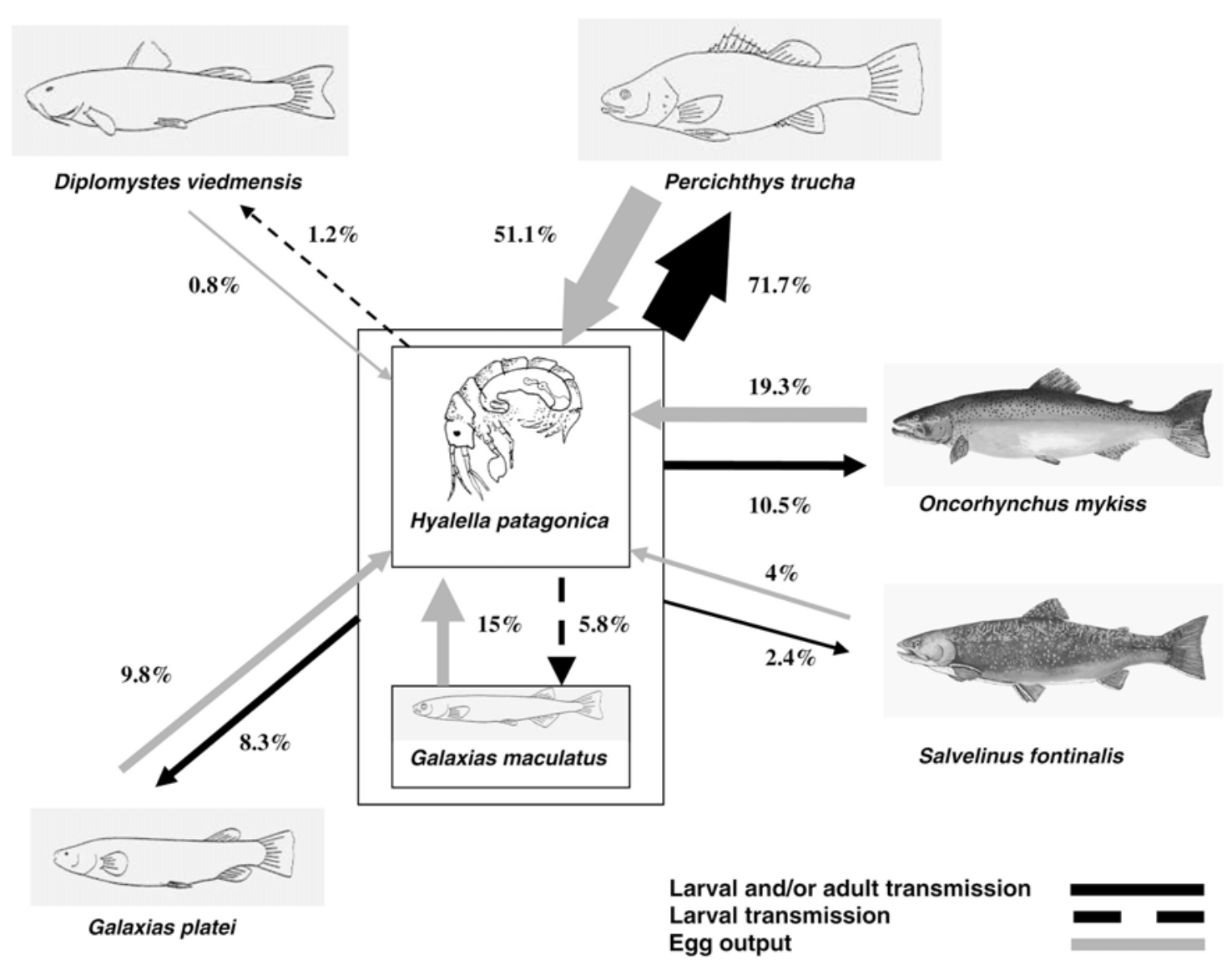

Fig. 1. Relative flow rates of Acanthocephalus tumescens in its hosts in Lake Moreno (the thickness of arrows indicates the relative values of parasite transmission and egg output).

Parasite population studies usually show a delicate equilibrium between reproductive and transmission efficiencies in the dynamics of life cycles considering, the same parasite species in a lake can be regulated in different ways depending on the host species and assemblages of them (Holmes et al. 1977, Aho and Kennedy 1987). Three ways in which the parasitic populations can be affected have been addressed (Bradley 1974, Holmes et al. 1977, Kennedy 1985): by transmission without regulation or by regulation at the level of the host population or at the level of the parasite's infrapopulation. Although several acanthocephalan-host interactions have been analysed, the regulatory mechanisms have been little considered because most studies have only examined one host species (Kennedy 1985).

Acanthocephalus tumescens does not provoke a strong tissue reaction in the host and encapsulation does not take place (Rauque et al. 2002), besides, in Lake Moreno high levels of infection were not registered. The establishment and the fecundity of females would not be affected by the presence of specimens of the same or different species, as the only negative correlation detected (between the abundance of $A$. tumescens and the abundance of Camallanus corderoi) has a low association value ( $\mathrm{rS}=-0.15)$, suggesting that neither regulation through mortality at the level of the host population nor intra- or interspecific interactions at the level of the parasite's infrapopulation take place.

Although a high percentage of females reached maturity in G. maculatus, O. mykiss and S. fontinalis (Table 2), the low values of prevalence and mean intensity and the low preference for $H$. patagonica suggest feeding habits would affect the populations of A. tumescens in them. Holmes et al. (1977) found this type of regulation in Metechinorhynchus salmonis parasitizing Coregonus artedii. In D. viedmensis and $G$. platei, the transmission from the intermediate host could not be the limiting factor of infection because fish of these species fed mainly on amphipods (Table 2) and besides, they had the highest values of prevalence and mean intensity, although $D$. viedmensis had the lowest percentages of F3 females (Table 1). Holmes et al. (1977) have also found this type of regulation in $M$. salmonis parasitizing Salvelinus namaycush. 
Holmes et al. (1977) found that only four of ten host species were important in maintaining the cycle of $M$. salmonis. In our study, four of six host species $(P$. trucha, O. mykiss and G. platei / G. maculatus) showed high values of relative parasite flow rates and egg output, but like the whitefish for M. salmonis in Cold Lake (Holmes et al. 1977), P. trucha was the main contributor for the suprapopulations of $A$. tumescens in Lake Moreno.

Five salmonid species were introduced into Patagonia at the beginning of the $20^{\text {th }}$ century (Navas 1987), and three of them inhabit Lake Moreno. Although there are no data on the relative abundance of native species before the introductions, $D$. viedmensis seems to be the most affected, being the least abundant today, probably due to predation by salmonids (Macchi et al. 1999). Acanthocephalus tumescens has been cited in Patagonia before the introduction of salmonids (von Linstow 1896) so, if $D$. viedmensis was more abundant, perhaps it played a more important role then than today in the sustaining of the A. tumescens suprapopulation. The low specificity and its capacity for post-cyclic transmission (Rauque et al. 2002) made A. tumescens a better coloniser than Pomphorhynchus patagonicus in Patagonian freshwater lakes. This ability and the introduction of exotic salmonid fishes allowed for the enlargement of the host range, so $O$. mykiss now harbours a large proportion of the adult component population of $A$. tumescens. The introduction of exotic salmonids seems to be less important for $P$. patagonicus since $O$. mykiss acts as a sink for this acanthocephalan species (Trejo 1994, Úbeda et al. 1994).

Acknowledgements. We are very grateful to Edward and Audrey Shaw for English revision of the manuscript. Samples were done under permission of local Government authorities. Financial support was provided by the Universidad del Comahue B-092 and Agencia Nacional de Promoción Científica y Tecnológica 01-402-3067.

\section{REFERENCES}

AHO J.M., KENNEDY C.R. 1987: Circulation pattern and transmission dynamics of the suprapopulation of the nematode Cystidicoloides tenuissima (Zeder) in the River Swincombe, England. J. Fish Biol. 31: 123-141.

AMIN O.M. 1987: Acanthocephala from lake fishes in Wisconsin: ecology and host relationships of Pomphorhynchus bulbocolli (Pomphorhynchidae). J. Parasitol. 73: 278-289.

BRADLEY D.J. 1974: Stability in host-parasite systems. In: M.B. Usher and M.H. Williamson (Eds.), Ecological Stability. Chapman \& Hall, London, pp. 71-87.

BUSH A.O., LAFFERTY K.D., LOTZ J.M., SHOSTAK A.W. 1997: Parasitology meets ecology on its own terms: Margolis et al. revisited. J. Parasitol. 83: 575-583.

CONOVER W.J. 1980: Practical Nonparametric Statistics. John Wiley \& Sons, New York, 493 pp.

CROMPTON D.W.T. 1983: Acanthocephala. In: K.G. Adiyodi and R.G. Adiyodi (Eds.), Reproductive Biology of Invertebrates. Vol. 1. Oogenesis, oviposition and oosorption. John Wiley \& Sons, New York, pp. 257-268.

ESCH G.W., FERNÁNDEZ J.C. 1993: A Functional Biology of Parasitism. Chapman \& Hall, London, 337 pp.

GIL de PERTIERRA A.A., SPATZ L., DOMA L.L. 1996: Systematics and metapopulation dynamics of Pomphorhynchus sphaericus n. sp. (Acanthocephala: Pomphorhynchidae) from freshwater siluriform fishes in the subtropical region of Argentina. Res. Rev. Parasitol. 56: 33-39.

HINE P.M., KENNEDY C.R. 1974: Observations on the distribution, specificity and pathogenicity of the acanthocephalan Pomphorhynchus laevis (Muller). J. Fish Biol. 6: 521-535.

HOLMES J.C. 1976: Host selection and its consequences. In: C.R. Kennedy (Ed.), Ecological Aspects of Parasitology, North-Holland Publishing Company, Amsterdam, pp. 2139.
HOLMES J.C. 1979: Parasite populations and host community structure. In: B.B. Kennedy (Ed.), Host-Parasite Interfaces. Academic Press, New York, pp. 27-46.

HOLMES J.C., HOBBS R.P., LEONG T.S. 1977: Populations in perspective: community organization and regulation of parasite populations. In: G.W. Esch (Ed.), Regulation of Parasite Populations. Academic Press, New York, pp. 209-245.

KENNEDY C.R. 1985: Regulation and dynamics of acanthocephalan populations. In: D.W.T. Crompton and B.B. Nickol (Eds.), Biology of the Acanthocephala. Cambridge University Press, Cambridge, pp. 385-416.

KENNEDY C.R. 1993: Acanthocephala. In: A.D. Adiyodi and K.G. Adiyodi (Eds.), Reproductive Biology of Invertebrates. Vol. 6. Asexual propagation and reproductive strategies. IBH, New Delhi, pp. 279-295.

MACCHI P.J., CUSSAC V.E., ALONSO M.F., DENEGRI M.A. 1999: Predation relationships between introduced salmonids and the native fish fauna in lakes and reservoirs in Northern Patagonia. Ecol. Freshwater Fish 8: 227-236.

NAVAS J.R. 1987: Los vertebrados exóticos introducidos en la Argentina. Rev. Mus. Arg. Cienc. Nat. "Bernardino Rivadavia", Zool., 14: 7-38.

NICKOL B.B. 1985: Epizootiology. In: D.W.T. Crompton and B.B. Nickol (Eds.), Biology of the Acanthocephala. Cambridge University Press, Cambridge, pp. 307-346.

ORTUBAY S.G., SEMENAS L.G., ÚBEDA C.A., QUAGGIOTTO A.E., VIOZZI G.P. 1994: Catálogo de Peces Dulceacuícolas de la Patagonia Argentina y sus Parásitos Metazoos. Dirección de Pesca, Río Negro, Argentina, $110 \mathrm{pp}$.

RAUQUE C.A., SEMENAS L.G., VIOZZI G.P. 2002: Postcyclic transmission in Acanthocephalus tumescens (Acanthocephala, Echinorhynchidae). Folia Parasitol. 49: 127-130. 
SEMENAS L., TREJO A. 1997: Redescription of Acanthocephalus tumescens (von Linstow, 1896) (Palaeacanthocephala: Echinorhynchidae) in Galaxias maculatus (Pisces: Galaxiidae) in Patagonia (Argentina). Syst. Parasitol. 36: 13-16.

TORRES P., CONTRERAS A., CUBILlOS V., GESCHE W., MONTEFUSCO A., REBOLLEDO C., MIRA A., ARENAS J., MIRANDA J., ASENJO S., SCHLATTER R. 1992: Parasitismo en peces, aves piscívoras y comunidades ribereñas de los Lagos Yelcho y TaguaTagua, X Región de Chile. Arch. Méd. Vet. 24: 77-92.

TORRES P., RUIZ E., REBOLLEDO C., MIRA A., CUBILlOS V., NAVARRETE N., GESCHE W., MONTEFUSCO A., VALDES L., ALBERDI A. 1990: Parasitismo en peces y comunidades humanas ribereñas de los Lagos Huillinco y Natri (Isla Grande de Chiloé), Chile. Bol. Chil. Parasitol. 45: 47-55.
TREJO A. 1994: Observations on the host specificity of Pomphorhynchus patagonicus (Acanthocephala) from the Alicura Reservoir (Patagonia, Argentina). J. Parasitol. 80: 829-830.

TREJO A., SEMENAS L., VIOZZI G. 2000: Acanthocephalus tumescens (Acanthocephala, Echinorhynchidae) in Galaxias maculatus (Pisces, Galaxiidae) of Lake Gutiérrez, Patagonia, Argentina. J. Parasitol. 86: 188-191.

ÚBEDA C., TREJO A., SEMENAS L., ORTUBAY S. 1994: Status of three different fish hosts of Pomphorhynchus patagonicus Ortubay, Úbeda, Semenas et Kennedy, 1991 (Acanthocephala) in Lake Rosario (Argentina). Res. Rev. Parasitol. 54: 87-92.

von LINSTOW O. 1896: Nemathelminthen. Hamburger Magalhaensische Sammelreise 3: 1-22.

Accepted 30 July 2002 